RU Традиции Ф. М. Достоевского в новелле Т. Манна «Алчущие»

Мельникова Л. А.

Аннотация. Цель исследования - выявить особенности художественного осмысления Т. Манном проблемы «маленького человека» в новелле «Алчущие» в контексте литературного влияния Ф. М. Достоевского. Посредством использования сравнительно-исторического метода выявляется ряд параллелей между эстетическими установками двух авторов в данном аспекте. В обоих текстах представлена попытка изучения внутренних переживаний героев, относящихся к категории «униженных и оскорбленных». Однако если русский писатель для решения данной художественной задачи использует самоисповедальные высказывания своих персонажей, то Т. Манн прибегает к приему «взгляд со стороны», репрезентируя в своем произведении точку зрения стороннего героя на проблему страдания «маленького человека». Научная новизна исследования заключается в том, что впервые в нем представлен опыт сравнительного анализа приемов психологизма, используемых в романе Ф. М. Достоевского «Бедные люди» и новелле Т. Манна «Алчущие». В результате установлено, что в интерпретации темы «униженных и оскорбленных» приоритет оба автора отдают необходимости проявления христианской любви к ближнему, осознанию недопустимости оскорбления человеческого достоинства «маленьких людей» ввиду их бедности и низкого социального статуса.

\title{
F. M. Dostoevsky’s Traditions in T. Mann's Short Story “The Hungry”
}

\author{
Melnikova L. A.
}

\begin{abstract}
The paper aims to reveal specificity of artistic interpretation of the "little man" theme in T. Mann's short story “The Hungry” in the context of F. M. Dostoevsky's literary influence. Relying on a comparative historical analysis, the researcher identifies similarity of the writers' aesthetic attitudes. Both the authors analyze internal experience of people regarded as "insulted and humiliated". To solve this artistic task, the Russian writer uses the personages' confessional monologues, whereas the German novelist uses the "outside view" technique representing an outsider's view on the problem of a "little man's" suffering. Scientific originality of the study lies in the fact that the researcher for the first time provides a comparative analysis of psychologism techniques used in F. M. Dostoevsky's novel "Poor Folk” and T. Mann's short story "The Hungry". As a result, it is shown that tackling the "little man" problem, both the authors emphasize the necessity of Christian love for one's neighbor, consider it impermissible to humiliate a "little man's" dignity because of his poverty and low social status.
\end{abstract}

\section{Введение}

Актуальность темы исследования обусловлена повышенным вниманием современного литературоведения к проблемам русско-немецкого литературного диалога, необходимостью всестороннего изучения специфики рецепции Т. Манном художественного опыта Ф. М. Достоевского.

Специфика литературно-критического и художественного осмысления Т. Манном личности и творчества многих русских классиков неоднократно оказывалась в поле исследовательского внимания отечественных и зарубежных литературоведов, среди них В. Х. Гильманов [2], И. Кузнецова [6], Ю. Леман [7], И. Мишин [10], Т. Д. Мотылева [11], М. Ю. Савельева [12], Г. Фридлендер [13], Г. В. Якушева [15]. Отношение к России и русской литературе было важным элементом мировидения немецкого писателя Томаса Манна (1875-1955). Значение русской классики для мировой культуры, с точки зрения данного автора, определяло «раскрытие психологических глубин, позволяющее увидеть их в процессе формирования (как в “Войне и мире” Л. Толстого) или распада (как в “Анне Карениной” Л. Толстого или “Преступлении и наказании” Ф. Достоевского) определенной цивилизационной эпохи и вместе с ней - системы ценностей, традиций, духовных и социальных 
“скреп”» [Там же, с. 82]. Русская литература являлась для Т. Манна источником творческого вдохновения и способствовала его становлению как писателя. В своей новелле «Тонио Крегер» он назвал русскую классику «святой». Чтение романа Л. Н. Толстого «Война и мир», по собственному признанию немецкого автора, помогло ему завершить работу на «Будденброками». При этом помимо Л. Н. Толстого большим авторитетом для Т. Манна был И. С. Тургенев: «Тргенева наряду с Т. Штормом Т. Манн считал своим духовным отцом... <...> В Толстом же - как и в Гете - Т. Манн видел ни с кем не сравнимого певца душевного здоровья и гармонии, величайшего эпика и романиста всех времен» [13, с. 371]. Ф. М. Достоевский же долгое время оставался на периферии писательского интереса данного немецкого автора.

В своей статье «Достоевский - но в меру» (1946) Т. Манн дает характеристику личности русского классика в контексте размышлений о других гениях: Толстом, Гете, Ницше. Рассуждая о причинах своего повышенного внимания к Гете и Толстому и стремлении свести к минимуму рассуждения о Ницше и Достоевском, немецкий писатель признается: «Мне было легко с воодушевлением и ласковой иронией воздавать должное божественным, осененным благодатью детям природы, которые были одарены возвышенным простодушием и несокрушимым здоровьем: автобиографическому аристократизму Гете... и эпической медвежьей силе, титанической первозданной свежести “великого писателя русской земли” Толстого... Но я испытываю робость, глубокую мистическую робость, повелевающую мне молчать, перед религиозным величием отверженных, перед гением как болезнью и болезнью как гением, перед теми, кто отягощен проклятием и одержимостью, в чьей душе святой неотторжим от преступника» [9].

Однако уже в начальный период своего творческого пути Т. Манн подвергал художественной переработке многие идеи текстов Ф. М. Достоевского. К числу проблем, одинаково волновавших и русского, и немецкого авторов, относилась проблема восприятия «униженных и оскорбленных», «маленьких» людей современным им социумом. В своей ранней новелле «Алчущие» (“Die Hungernden”, 1903) Т. Манн, по мнению некоторых исследователей, развивает традиции «Бедных людей» Ф. М. Достоевского [10].

Для осмысления особенностей рецепции Т. Манном традиций Ф. М. Достоевского в новелле «Алчущие» в статье использовались следующие методы исследования: сравнительно-исторический, метод целостного анализа художественного произведения.

Теоретической базой исследования послужили работы М. М. Бахтина [1], И. Мишина [10], Г. Фридлендера [13; 14].

Для достижения поставленной цели исследования необходимо решить следующие задачи: выявить особенности интерпретации в новелле Т. Манна «Алчущие» проблемы взаимоотношения художника и общества; определить специфичные черты раскрытия темы «маленького человека» в новелле; проанализировать символику названия произведения; охарактеризовать используемые Т. Манном приемы психологизма в контексте литературного влияния Ф. М. Достоевского.

Практическая значимость нашего исследования заключается в возможности использования его выводов в курсах по истории зарубежной литературы XX в., истории немецкой литературы XX в., истории русской литературы XIX в., спецкурсах, посвященных проблемам русско-зарубежных литературных взаимосвязей.

\section{Проблема взаимодействия художника и социума в новелле}

Одной из центральных в новелле «Алчущие» является проблема одиночества и отчуждения. Она осмысливается в произведении в двух основных направлениях: 1) с помощью изображения особенностей взаимоотношений художника и общества; 2) посредством репрезентации образа «маленького человека». Т. Манн подвергает развернутому психологическому анализу внутренний мир и переживания типичного интеллигента эпохи рубежа XIX-XX веков. Так как в новелле сделан акцент на изображении душевных коллизий героя, развернутый портрет-представление данного персонажа в произведении отсутствует. Центральный герой «Алчущих» - художник Детлеф - осознает свою трагическую отстраненность от социума, ему сложно адаптироваться в окружающей его среде. Автор показывает нам постепенное самораскрытие героя посредством использования приема внутреннего монолога. Своеобразным толчком, способствующим началу исповеди отвергнутого своей возлюбленной во время шумного театрального празднества художника, становится пародийное исполнение актерами мелодий из оперы Вагнера «Тристан и Изольда». Соприкосновение с произведением искусства обнажает «болевые точки» в душе данного персонажа, обостряя чувство одиночества и ощущение собственной ненужности. Служение искусству наложило сильный отпечаток на образ жизни Детлефа, легкость и непринужденность в поведении оказываются ему недоступны, их заменяют медлительность и серьезность. Осознание героем своей непохожести на остальных ведет к четкому разделению в его сознании людей на страдающих творцов и «голубоглазых, которые не нуждаются в духовном». В результате в произведении возникают оппозиции: художник - филистеры, «ледяной мир искусства» - обывательская жизнь. Описывая процесс наблюдений Детлефа за поведением праздничной толпы зрителей в театре, Т. Манн фиксирует динамику отношения героя к филистерской массе людей: оно варьируется от самолюбивого осознания персонажем своей власти над ними, основанной на проницательности и способности запечатлеть их на картине и тем самым заставить весь мир любоваться их изображением, до обостренного желания войти в их круг и быть принятым среди них как равный. В своих внутренних монологах, обращенных 
к толпе, Детлеф касается вопроса искренности художников по отношению к филистерам: «Не думайте, что дух презирает вас. Не верьте его пренебрежительной гримасе. Мы крадемся за вами следом... и в наших жадно устремленных на вас глазах горит страстное желание уподобиться вам» [8, с. 189].

Детлеф дает развернутую характеристику того типа художников-интровертов, к которому он относится, и формулирует основную потребность его представителей - быть включенными в обыденный, заурядный круговорот жизненной повседневности. Внутренний конфликт, переживаемый в связи с этим персонажем, основан на столкновении в его душе чувства и долга: «Ах, хоть на один только вечер быть не художником, а человеком! <...> Хоть раз с открытым сердцем и душой попросту жить, любить, радоваться! Хоть раз побыть с вами, в вас, быть вами, живущими! Хоть раз насытиться, вкусив блаженства обыденности!» [Там же, с. 190].

Внутренняя драма героя заключается в понимании им невозможности достижения полноты бытия, ущербности собственного образа жизни. Тот факт, что потребность в теплоте человеческого общения и ласке не находит удовлетворения, вызывает в его душе разочарование и тоску. Эти чувства являются началами, во многом определяющими его мироотношение.

\section{Тема «маленького человека» в новелле}

Рефлексирующий, мятущийся, обладающий тонкой душевной организацией Детлеф после ухода из театра, в котором его любимая Лили осталась развлекаться с другим, встречает на улице нищего.

Приведенные в данном эпизоде портретные характеристики встретившихся взглядами героев содержат ряд выразительных деталей-штрихов, которые сопоставляются друг с другом по принципу контраста. «Страдальческое лицо», «потрепанная куртка с поднятым воротником», «сжатые в кулаки руки», «впалые щеки» прохожего противопоставляются «меховому воротнику добротной шубы», «театральному биноклю», «лакированным туфлям» и «серебряному портсигару» Детлефа. Материальное благополучие Детлефа вызывает у прохожего желание подразнить того своим оборванным видом и вместе с тем язвительно выразить свое презрение. Во время этой кратковременной встречи между персонажами не возникает непосредственного вербального диалога, взаимодействие ограничивается лишь небольшим визуальным контактом. Однако в душе художника эта встреча производит переворот, она укрепляет его в убеждении, что уровень финансового благополучия, внешняя оболочка не могут быть главными разграничительными критериями между людьми. Мысленно для себя Детлеф заключает «Мы - братья!» [Там же, с. 192].

Размышляя о поэтике Достоевского в ранний период его творчества, исследователи отмечают тот факт, что во многих текстах писателя доминирует «мысль о том, что самое страшное унижение для человека пренебрежение личностью последнего, заставляющее его чувствовать себя ничтожной, затертой грязными ногами “ветошкой” $[14$, с. 9]. Точно так же мысль о возможном унижении человеческого достоинства бедного прохожего поражает манновского Детлефа и заставляет его удержаться от вступления с ним в разговор с целью каких-либо оправданий.

Гуманизм, милосердие и способность к состраданию занимают ведущее место в системе ценностей Детлефа. Он понимает, что, несмотря на внешние различия, между ним и бедным прохожим есть много глубинных параллелей. Ретроспективное мысленное обращение манновского героя к этому случайно встреченному им «маленькому человеку» выражает сущность его взглядов на имеющиеся между ними сходства: «Ничто мне не чуждо из снедающих тебя мук, а ты думал меня пристыдить? <...> Что такое искусство? Переплавленная в образы тоска. И родина у нас одна с тобой - страна обманутых, алчущих, неприемлющих, и даже предательские часы презрения к себе знакомы нам обоим, часы, в которые мы томимся постыдной любовью к жизни, жаждой глупенького счастья. Но ты меня не признал» [8, с. 193].

\section{Символика названия новеллы}

В данном контексте особым символизмом наделено название новеллы - “Die Hungernden” (oт нем. der Hunger - голод, сильное желание), в русском переводе «Алчущие». Данное причастие образовано от глагола «алкать». Современный толковый словарь русского языка Т. Ф. Ефремовой дает следующее толкование данной дефиниции: 1. испытывать голод; 2. страстно желать чего-либо, испытывать непреодолимое стремление к чему-либо [4]. Учитывая проблематику произведения, можно констатировать, что по отношению к героям Т. Манна алчущие - это не только испытывающие голод, но и нуждающиеся в чем-либо, жаждущие чего-то. Данное заглавие можно рассматривать в качестве обобщенного определения представителей той социальнопсихологической общности людей (творцов-интровертов из числа интеллигентов), к которой принадлежит Детлеф и от имени которой он произносит следующее признание, являющееся, по сути, самохарактеристикой: «...уединенные мечтатели и обездоленные жизнью... мы нищие призраки бытия... все мы таим в себе щемящую тоску по простодушным, обыкновенным, живым, по малой толике дружеского тепла, преданности, доверчивой близости, по человеческому счастью» [8, с. 188].

В то же время после встречи с «маленьким человеком» Детлеф приходит к пониманию того, что «алчущие» - это одинокие и отвергаемые социумом люди различных социальных групп и возрастов, испытывающие 
острую потребность в признании, понимании, избавлении от своих страданий, связанных с их отчужденностью. И Детлефа, и бедного прохожего объединяет стремление к полноценной жизни, которая состоит не только из материального достатка, но и возможности непосредственного, живого, непринужденного общения и взаимопонимания между людьми. Род деятельности Детлефа, понимание им необходимости следовать возложенной на него миссии делают его слишком непохожим на других, это мешает его ассимиляции с обществом, превращая этого персонажа тем самым в чужеродный для социума элемент. Но окружающих отталкивает от него прежде всего его внутренняя составляющая, в то время как бедный прохожий оказывается в категории «отверженных» в первую очередь из-за своей потрепанной одежды и неухоженного и изнеможденного внешнего вида. Имплицитно в своем монологе Детлеф пытается оспорить расхожее убеждение бедных людей о презрительном отношении к ним любого богатого барина. Герой-интеллигент показывает своим примером, что независимо от социального статуса испытывать одинаковую душевную боль могут и бедные, и материально обеспеченные. Он оказывается чужд снобизма и высокомерия и, исходя из того, что страдание может выступать в качестве объединяющей силы людей, ставит знак равенства между собой и случайно встреченным им представителем социального дна.

Неравнодушие к страданиям ближнего, стремление к альтруизму сближают данного персонажа Т. Манна с героями «Бедных людей» Ф. М. Достоевского. Но если в романе Ф. М. Достоевского «бедные люди» сами выражают свои душевные переживания и страхи посредством переписки, то в новелле Т. Манна делается попытка репрезентации стороннего взгляда на «маленького человека». Носителем данной точки зрения оказывается лишенный поверхностности и стремящийся к выявлению глубинных причин душевных терзаний «маленьких людей» страдающий герой-художник. В то же время эстетические установки Т. Манна и Ф. М. Достоевского при изображении «униженных и оскорбленных» героев сближаются в аспекте акцентирования значимости христианской любви к ближнему.

В то же время нельзя не отметить того, что в образе Детлефа присутствует полемика с традициями романтизма. Сохраняя оппозицию «художник - филистеры», Т. Манн в то же время показывает, что его персонаж тяготится своей исключительностью и стремится не уйти от действительности или противопоставить себя ей, a, наоборот, хочет быть принятым ей и насладиться простым и непринужденным человеческим общением, в том числе и с обыденными людьми. В образе Детлефа также отсутствует романтическая отстраненность от реальности: сохраняя сосредоточенность на своем внутреннем мире, персонаж Т. Манна в то же время обращает внимание и на состояние других людей, по сути, являющих собой таких же страдальцев, как и он.

Признаки литературного влияния Ф. М. Достоевского присутствуют в «Алчущих» и в аспекте психологизма. М. М. Бахтин, характеризуя поэтику раннего романа русского классика, указывал на тот факт, что «в своем первом произведении Достоевский вырабатывает столь характерный для всего его творчества речевой стиль, определяемый напряженным предвосхищением чужого слова. Значение этого стиля в его последующем творчестве громадно: важнейшие исповедальные самовысказывания героев проникнуты напряженнейшим отношением к предвосхищаемому чужому слову о них, чужой реакции на их слово о себе» [1, с. 229]. Варенька Доброселова и Макар Девушкин в своей переписке предвосхищают и учитывают потенциальную вербальную реакцию собеседника на их слова и поступки. Так, например, Девушкин, рассуждая о том, какую книгу прислать Варваре, пишет: «Я просил ее для себя; обещались препроводить. Только будете ли вы-то читать? Вы у меня на этот счет привередница; трудно угодить на ваш вкус, уж я вас знаю, голубчик вы мой; вам, верно, все стихотворство надобно, воздыханий, амуров, - ну, и стихов достану, всего достану» [3, с. 53]. Детлеф также в своих внутренних монологах выстраивает собственное высказывание, проецируя при этом потенциальную реакцию воображаемого собеседника: «Разве в этой дрожи, в этой горькой и язвительной гримасе не проскальзывало желание поразить самодовольного счастливчика... заставить смущенно призадуматься, страдать? Но ты заблуждаешься, приятель, ты не достиг желаемого эффекта» [8, с. 192].

Героев Т. Манна и Ф. М. Достоевского роднит и сочувствующее отношение к бедственному положению других людей. Девушкин, описывая в письме Вареньке своих соседей по квартире, особое внимание уделяет бывшему чиновнику Горшкову, признаваясь в том, что созерцание бедности и угнетенности семьи последнего вызывает в его душе глубокую печаль и жалость.

Бедный человек, но человек с «амбицией», каким является Макар Девушкин, по замыслу Достоевского, постоянно чувствует на себе «“дурной взгляд” чужого человека, взгляд или попрекающий, или... насмешливый (для героев более гордого типа самый дурной чужой взгляд - сострадательный)... <..> Девушкин вечно прислушивается к чужим словам о нем» [1, с. 230]. Подобно «бедным людям» русского классика, «маленький человек» Т. Манна также оказывается остро восприимчив к чужой реакции на свою бедность, но в отличие от Макара Девушкина он не только не боится чужого взгляда, но и, более того, стремится задержать на себе взгляд случайно встреченного им Детлефа для того, чтобы выразить свое пренебрежительное к нему отношение и вызвать у последнего укоры совести и чувство вины за свое финансовое благополучие.

Размышляя о поэтике романа Ф. М. Достоевского «Бедные люди», В. Н. Захаров указывает на то обстоятельство, что «бедные люди живут трудно, тяжело, страдают и сострадают, помогают друг другу, умеют делать добро ближним, довольствоваться малым» [5, с. 82]. У героев Достоевского нет стремления продемонстрировать свою бедность материально обеспеченным и заострять их внимание на собственном бедственном положении с целью назидательного морального воздействия на них. В то время как в новелле Т. Манна «маленький человек» 
показан эпизодически, а потому и не столь разнопланово, акцент в изображении бедного героя сделан на его обидном осознании собственной приниженности во время случайной встречи с «богатым барином».

\section{Заключение}

Тема отчуждения между людьми является основной в новелле Т. Манна. Писатель в своем произведении пытается показать, как отчуждение проявляется между представителями различных социальных групп. Главный вывод, к которому он приходит: лишь страдая сам, другой человек, подобно Детлефу, может задуматься о страданиях ближнего. Т. Манн в «Алчущих» «устами героя новеллы заявляет, что истинный художник должен быть гуманистом и особенно обязан любить людей униженных и страдающих» [10, с. 28].

На основании проведенного исследования можно констатировать, что традиции «Бедных людей» Ф. М. Достоевского в новелле «Алчущие» развиваются в следующих аспектах: 1) сквозной в обоих произведениях является тема страдания и одиночества; 2) обоим текстам оказывается присущ гуманистический пафос, раскрытие которого тесно связано с концепцией христианской любви к ближнему, недопустимости оскорбления человеческого достоинства «маленьких людей» ввиду их бедности и низкого социального статуса; 3) повествовательная техника в обоих произведениях ориентирована на использование приема предвосхищения чужого слова.

Однако если в романе Ф. М. Достоевского «Бедные люди» самораскрытие героев происходит посредством переписки, несущей исповедальное начало, в новелле Т. Манна нет непосредственных высказываний «маленького человека», размышления о его судьбе даны с помощью репрезентации внутреннего монолога персонажа, наблюдающего за бедным прохожим со стороны. Тем самым в произведении получает отражение идея писателя о незримом единстве людей различных социальных статусов и уровней материального достатка. Выбор в качестве наблюдателя художника можно трактовать также как показатель убежденности Т. Манна в том, что интеллигенция не должна отгораживаться от страданий «униженных и оскорбленных», считая их изгоями общества, а наоборот, активно способствовать изменению отношения социума к данной категории - от высокомерного пренебрежения к состраданию и приятию. Сказанное свидетельствует о том, что немецкий писатель не создает текст, подражательный по отношению к текстам русского автора, но подвергает глубокому художественному осмыслению идеи и художественные приемы Ф. М. Достоевского, сообщая при этом дополнительные смыслы поэтике своей новеллы.

\section{Источники | References}

1. Бахтин М. М. Проблемы поэтики Достоевского // Бахтин М. М. Собрание сочинений: в 7-ми т. М.: Языки славянских культур, 2012. Т. 6. С. 6-300.

2. Гильманов В. Х. Русский курсив в творческой судьбе Томаса Манна // Формирование образов России и русских в западных дискурсивных практиках XX-XXI веков: материалы Междунар. науч. конф. / отв. ред. А. Э. Воротникова. Воронеж, 2018. С. 275-293.

3. Достоевский Ф. М. Бедные люди // Достоевский Ф. М. Собрание сочинений: в 12-ти т. М.: Правда, 1982. T. $1.384 \mathrm{c.}$

4. Ефремова Т. Ф. Современный толковый словарь русского языка [Электронный ресурс]. URL: https://dic. academic.ru/dic.nsf/efremova/137856 (дата обращения: 25.06.2021).

5. Захаров В. Н. Имя автора - Достоевский: очерк творчества. М.: Индрик, 2013. 456 с.

6. Кузнецова И. Следы Достоевского на снегу «Волшебной горы» Томаса Манна // Достоевский: материалы и исследования. 2013. Т. 20. С. 439-454.

7. Леман Ю. Русская литература в Германии. Восприятие русской литературы в художественном творчестве и литературной критике немецкоязычных писателей с XVIII века до настоящего времени. М.: ЯСК, 2018. 480 с.

8. Манн Т. Алчущие // Манн Т. Собрание сочинений: в 10-ти т. М.: Гос. изд-во худож. лит., 1960. Т. 7. Рассказы. С. 186-193.

9. Манн Т. Достоевский - но в меру [Электронный ресурс]. URL: https://burusi.wordpress.com/2013/03/03/ tomas-mann/(дата обращения: 05.07.2021).

10. Мишин И. Достоевский и зарубежные писатели (основные проблемы творчества, традиции и новаторство): учеб. пособие по спецкурсу. Ростов н/Д, 1974. 135 с.

11. Мотылева Т. Томас Манн и русская литература [Электронный ресурc]. URL: https://www.litmir.me/br/ ?b=244783\&p=7 (дата обращения: 06.07.2021).

12. Савельева М. Ю. Федор Достоевский и Томас Манн о «Сумерках германского духа» // Человек. 2014 . № 2. C. 168-175.

13. Фридлендер Г. Достоевский и мировая литература. М.: Худож. лит., 1979. 423 с.

14. Фридлендер Г. Ф. М. Достоевский и его наследие // Достоевский Ф. М. Собрание сочинений: в 12 -ти т. М.: Правда, 1982. Т. 1. С. 3-36.

15. Якушева Г. В. Генрих Манн и Томас Манн о России // Россия - Германия: литературные встречи (1880-1945). М.: ИМЛИ, 2017. С. 70-89. 


\section{Информация об авторах | Author information}

RU Мельникова Любовь Александровна ${ }^{1}$, к. филол. н.

${ }^{1}$ Балашовский институт (филиал)

Саратовского национального исследовательского государственного университета имени Н. Г. Чернышевского

EN Melnikova Lyubov Alexandrovna ${ }^{1}, \mathrm{PhD}$

${ }^{1}$ Balashov Institute (Branch) of Saratov State University

${ }^{1}$ Imelnikova5@mail.ru

\section{Информация о статье | About this article}

Дата поступления рукописи (received): 07.07.2021; опубликовано (published): 15.09.2021.

Ключевые слова (keywords): Т. Манн; Ф. М. Достоевский; психологизм; маленький человек; униженные и оскорбленные; T. Mann; F. M. Dostoevsky; psychologism; little man; insulted and humiliated. 